\title{
SISTEM PENDUKUNG KEPUTUSAN PEMILIHAN OLI MESIN YAMAHA MIO
}

\author{
Silvana Marsela[1]; Eka Wulansari Fridayanthie ${ }^{[2]}$; Maryanah Safitri ${ }^{[3]}$; Faridi[i[ ${ }^{4]}$ \\ Program Studi Sistem Informasi[1][2] \\ Program Studi Teknik Informatika[3][4] \\ STMIK Nusa Mandiri Jakarta[1][3] \\ Universitas Bina Sarana Informatika ${ }^{[2]}$ \\ Universitas Muhammadiyah Tanggerang[4] \\ www.nusamandiri.ac.id ${ }^{1[1][3]}$, www.bsi.ac.id[2], www.umt.ac.id ${ }^{[4]}$ \\ silvana.marshel4@gmail.com ${ }^{[1]}$; eka.ewf@bsi.ac.id[2]; maryanah.msf@nusamandiri.ac.id[3]; \\ faridimkom@gmail.com ${ }^{[4]}$
}

\begin{abstract}
There are still many people today who do not fully understand how to choose the best lubricating oil for automatic motorcycles, especially Yamaha Mio. They just choose the lubricating oil based on a recommendation from the motorcycle manufacturer or by viewing the famous brands only and does not understand how the characteristics and type of lubricating. Impact wrong choosing engine oil may decrease engine performance motorcycle. For this reason, knowledge is needed about the criteria that are a priority consideration in the selection of engine oil and facilitate the selection process so that it does not require a long time in the selection. By using the Analiytical Hierarchy Process (AHP) method and with data collection techniques using observation, interviews, questionnaires and literature studies then it can help in the selection of engine oil in accordance with the types of automatic motorcycles, especially Yamaha Mio.

Key word: SPK, Engine Oil Selection, AHP
\end{abstract}

Intisari- Masih banyak masyarakat saat ini yang belum memahami sepenuhnya bagaimana memilih minyak pelumas yang terbaik untuk sepeda motor matic, khususnya Yamaha Mio. Mereka hanya memilih minyak pelumas berdasarkan rekomendasi dari pabrikan sepeda motor atau dengan melihat merk yang terkenal saja dan tidak memahami bagaimana karakteristik dan jenis dari pelumas tersebut. Dampak salah memilih oli mesin dapat mengalami penurunan performa mesin sepeda motor. Untuk itu, diperlukan diperlukan pengetahuan mengenai kriteria yang menjadi prioritas pertimbangan dalam pemillihan oli mesin serta memudahkan proses pemilihan agar tidak membutuhkan waktu yang panjang dalam pemilihan. Dengan menggunakan metode Analytical Hierarchy Process (AHP) dan dengan teknik pengumpulan data menggunakan observasi, wawancara, kuesioner serta studi pustaka maka dapat membantu dalam pemilihan oli mesin yang sesuai dengan jenis kendaraan matic khususnya Yamaha Mio.

Hasil dari penelitian ini, Vrooam Scooter menduduki prioritas pertama dengan bobot 1,665 diikuti oleh Repsol Matic prioritas ke-2 dengan bobot 1,278 dan Yamalube Matic pada prioritas ke-3 dengan bobot 1,506. Oli Mesin Yamaha Mio yang banyak dipilih oleh pelanggan dengan menggunakan Analytical Hierarchy Process (AHP) pada Bengkel Blessing Motorsport Tangerang adalah Vrooam Scooter.

Kata Kunci: SPK, Pemilihan Oli Mesin, AHP

\section{PENDAHULUAN}

Masih banyak masyarakat saat ini yang belum memahami sepenuhnya memilih minyak pelumas yang terbaik untuk sepeda motor matic, khususnya Yamaha Mio. Mereka hanya memilih minyak pelumas berdasarkan beberapa faktor seperti harga, ketersediaan minyak pelumas, rekomendasi pabrik, serta daya tahan dari minyak pelumas(Manila, Sutrisno, \& Neyland, 2014) atau dengan melihat merk yang terkenal saja dan tidak memahami karakteristik dan jenis dari pelumas tersebut. Dampak salah memilih oli mesin dapat mengalami penurunan performa mesin sepeda motor. Bagi banyak orang yang belum mengetahui apa fungsi dari pelumasan oli pada mesin, semua mesin yang di operasikan tentu harus menggunakan oli, dimana oli adalah jantung bagi setiap mesin yang terus memutar atau bekerja (Aisyah \& Putra, 2019).

Oli adalah pelumas yang banyak digunakan dari berbagai mesin seperti, Genset, Mobil, Kapal dan berbagai mesin yang ada di dunia ini. Didalam sebuah mesin terdapat berbagai komponen yang ada, dan tentu setiap komponen tersebut memiliki berbagai fungsi yang berbeda pula. Untuk mengatasi hal 
tersebut, maka dibutuhkan pelumas yaitu oli, yang dapat mengurangi kehausan karena gesekan setiap kompoen yang terdapat di dalam mesin. Untuk itu tujuan penelitian ini adalah sebagai pengetahuan bagi konsumen mengenai kriteria yang menjadi prioritas pertimbangan dalam pemillihan oli mesin serta memudahkan proses pemilihan agar tidak membutuhkan waktu yang panjang dalam pemilihan. Dengan menggunakan metode Analytical Hierarchy Process (AHP) dan dengan teknik pengumpulan data menggunakan observasi, wawancara, kuesioner serta studi pustaka maka dapat membantu dalam pemilihan oli mesin yang sesuai dengan jenis kendaraan matic khususnya Yamaha Mio pada Bengkel Blessing Motorsport Tangerang.

\section{BAHAN DAN METODE}

\section{A. Tahapan Penelitian}

Dalam penelitian ini dilakukan 4 (empat) tahap penelitian yaitu :

1. Pengamatan Langsung (Observasi)

Penulis melakukan penelitian dan pengumpulan data dengan cara mencari datadata dari sumber yang ada seperti responden yang menggunakan oli mesin di Bengkel Blessing Motorsport.

2. Wawancara (Interview)

Untuk melengkapi data-data yang dibutuhkan penulis melakukan tanya jawab secara langsung dengan pengguna dari kalangan pelanggan yang membeli oli mesin.

3. Angket (Kuesioner)

Penulis menyebarkan lembar kuesioner kepada customer yang membeli oli mesin di Bengkel Blessing Motorsport.

4. Studi Pustaka

Studi pustaka dilakukan dengan mencari bahan-bahan dari literatur atau contoh kasus yang serupa yang ada di perpustakaan Sekolah Tinggi Manajemen Informatika dan Komputer (STMIK) Nusa Mandiri, internet dan lainnya yang berhubungan dengan permasalahan yang akan dibahas.

\section{B. Penelitian Terkait}

Adapun penelitian sebelumnya yang berhubungan dengan penelitian ini antara lain yaitu:

a. Menurut (Rianto \& Halen, 2016) Penelitian ini bertujuan untuk menentukan sepeda motor matic terbaik. Karena dalam pemilihan sepeda motor matic, tentu para konsumen ingin mendapatkan pilihan yang terbaik dan cepat. Hampir setiap konsumen menginginkan sepeda motor matic yang harganya terjangkau, irit bahan bakar, dan nyaman digunakan. Oleh karena itu dibutuhkan suatu sistem pendukung keputusan yang dapat membantu konsumen dalam menentukan sepeda motor matic terbaik sesuai dengan keinginan konsumen. Pada penelitian ini peneliti sendiri menggunakan metode Analytical Hierarchy Process (AHP) dalam proses menentukan sepeda motor matic terbaik. Pada penelitian ini pengujian data diperoleh dari kuesioner dan wawancara dengan narasumber. Data yang telah diperoleh tersebut diuji dengan menggunakan software expert choice untuk menentukan sepeda motor matic yang terbaik. Sistem pendukung keputusan ini diharapkan dapat membantu dan memudahkan konsumen dalam pemilihan sepeda motor matic terbaik dan dapat menghasilkan suatu hasil optimal yang memenuhi rasa kepuasan tinggi bagi konsumen dalam memilih sepeda motor matic yang terbaik.

b. Menurut (Aisyah \& Putra, 2019) Penelitian ini bertujuan untuk memilih oli sepeda motor matic terbaik. Bagi banyak orang yang belum mengetahui apa fungsi dari pelumasan oli pada mesin, semua mesin yang di operasikan tentu harus menggunakan oli, dimana oli adalah jantung bagi setiap engine yang terus memutar atau bekerja. Didalam sebuah mesin terdapat berbagai komponen yang ada, dan tentu setiap komponen tersebut memiliki berbagai fungsi yang berbeda pula. Untuk mengatasi hal tersebut, maka dibutuhkan pelumas yaitu oli, untuk dapat mengurangi kehausan karena gesekan setiap komponen yang terdapat di dalam mesin. Dalam penelitian ini rumusan masalah yang ditentukan adalah bagaimana memilih oli sepeda motor matic terbaik dengan menggunakan sistem pendukung keputusan sebagai sebuah sistem berbasis komputer yang nantinya digunakan dalam memilahmilah dari berbagai macam oli yang dipasarkan. Penelitian ini menerapkan Metode Preference Selection Index (PSI) dalam pemilihan oli sepeda motor matic terbaik berdasarkan kriteria dengan menggunakan rumus yang hasilnya lebih akurat dan tepat sasaran.

\section{HASIL DAN PEMBAHASAN}

Dalam pengolahan hasil dari penelitian ini, maka penulis menetapkan proses pemecahan 
masalah dalam AHP dengan langkah-langkah penyelesaian berdasarkan empat tahap yaitu mendefinisikan masalah, menentukan prioritas elemen, sintesis dan mengukur konsistensi.

\section{A. Mendefinisikan Masalah}

Tahapan pendefinisian masalah dalam penelitian ini dipakai untuk memecahkan masalah yang besar serta menyederhanakannya menjadi permasalahan yang kecil yang akan digambarkan dalam sebuah bentuk hirarki.

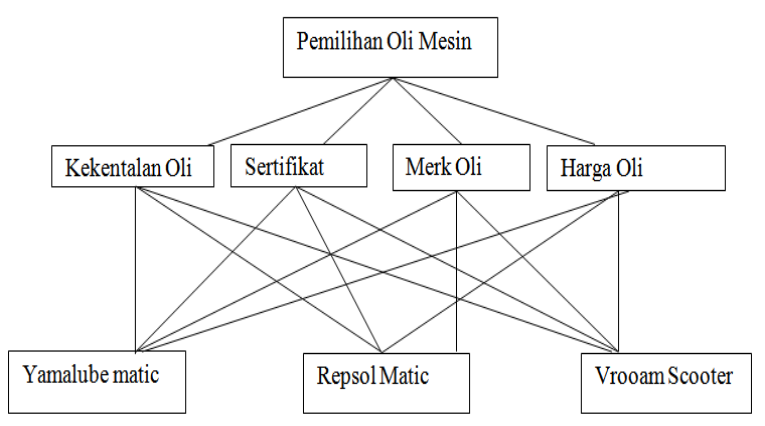

Sumber : (Marsela et al., 2019)

Gambar1. HIrarki Pemilihan Oli Mesin

Tabel 1. Penjelasan Hirarki Pemilihan Oli Mesin

\begin{tabular}{ll}
\hline Tujuan & Penjelasan \\
\hline Pemilihan Oli & Sasaran yang ingin dicapai oleh \\
Mesin & Bengkel Blessing Motorsport \\
& untuk penentuan jenis Oli \\
& Mesin yang sesuai untuk \\
& Yamaha Mio bagi pelanggan.
\end{tabular}

\begin{tabular}{ll}
\hline Kriteria & Penjelasan \\
\hline Kekentalan & $\begin{array}{l}\text { Kriteria yang merupakan salah } \\
\text { Satu faktor penting dalam oli } \\
\text { mesin. }\end{array}$ \\
\hline Sertifikat Oli & $\begin{array}{l}\text { Kriteria yang menunjukkan } \\
\text { bahwa Oli Mesin memiliki }\end{array}$ \\
& sertifikat internasional. \\
\hline Merk Oli & Kriteria yang menunjukkan \\
& merk yang ada pada oli mesin. \\
\hline Harga Oli & Kriteria yang menunjukkan \\
& faktor harga pada oli mesin. \\
\hline
\end{tabular}

Sumber: (Marsela et al., 2019)

B. Menentukan Prioritas Elemen

Cara menentukan prioritas elemen adalah membuat perbandingan berpasangan, dengan membandingkan elemen sesuai kriteria yang diberikan dengan menggunakan bentuk matriks (Setiawan, 2016). Untuk memulai proses perbandingan berpasangan dimulai dari level paling atas hirarki untuk memilih kriteria. Dalam mengisi proses perbandingan berpasangan menggunakan bilangan untuk merepresentasikan kepentingan relatif dari satu elemen terhadap elemen lain. Bilangan yang dimaksud dalam bentuk skala 1 sampai 9.

Pada Penelitian ini, penulis mengikutsertakan responden yang merupakan pelanggan tetap Bengkel Blessing Motorsport. Untuk kuesioner dibagikan kepada responden yaitu sebagai berikut :

Tabel 2 Level 1 : Perbandingan Kriteria Utama

\begin{tabular}{|c|c|}
\hline $\begin{array}{l}\text { Dalam penentuan pemilihan } \\
\text { Oli Mesin untuk Yamaha Mio, } \\
\text { Kriteria manakah yang lebih } \\
\text { penting dibandingkan } \\
\text { kriteria-kriteria berikut? }\end{array}$ & $\begin{array}{c}\text { Berapa Tingkat } \\
\text { Kepentingannya? }\end{array}$ \\
\hline $\begin{array}{ll}\text { Kekental } & \text { Sertifikat } \\
\text { an Oli } & \text { Oli }\end{array}$ & 12234556789 \\
\hline $\begin{array}{l}\text { Kekental } \\
\text { an Oli }\end{array}$ & 123456789 \\
\hline $\begin{array}{l}\text { Kekental } \\
\text { an Oli }\end{array}$ & 1223456789 \\
\hline $\begin{array}{l}\text { Sertifikat } \\
\text { Oli }\end{array}$ & 1223456789 \\
\hline $\begin{array}{l}\text { Sertifikat } \\
\text { Oli }\end{array}$ & 1233456789 \\
\hline Merk Oli & 123456789 \\
\hline
\end{tabular}

Sumber: (Marsela et al., 2019)

Keterangan :

1 = Sama pentingnya

7 = Jauh lebih penting

3 = Sedikit lebih penting

$=$ Mutlak lebih penting daripada

$5=$ Lebih Penting daripada

2,4,6,8 = Nilai Antara dua pertimbangan

Setelah data dari kuesioner diisi oleh responden dan dikumpulkan, selanjutnya dirangkum dalam bentuk empat tabel matriks perbandingan berpasangan, yaitu :

1. Matriks perbandingan berpasangan level 1 berdasarkan kriteria utama

2. Matriks perbandingan berpasangan level 2 berdasarkan kriteria Kekentalan Oli

3. Matriks perbandingan berpasangan level 2 berdasarkan kriteria Sertifikat Oli

4. Matriks perbandingan berpasangan level 2 berdasarkan kriteria Merk Oli

5. Matriks perbandingan berpasangan level 2 berdasarkan kriteria Harga Oli.

Dalam Penelitian ini penulis menggunakan beberapa kriteria dan alternatif dalam pengolahan data dengan menggunakan Ms.Excel, dimana kriteria yang terdiri dari 
kekentalan Oli, Sertifikat Oli, Merk Oli dan Harga Oli, maka selanjutnya adalah menginput data perbandingan alternatif. Alternatif yang dipilih harus memenuhi kriteria yang sebelumnya sudah diperoleh yakni Yamalube Matic, Repsol Matic dan Vrooam Scooter.

Dalam matriks perbandingan berpasangan, data diperoleh dari responden yang berjumlah 10 orang, maka perlu dibuat rata-rata untuk masing-masing elemen perbandingan dengan cara mengalikan semua elemen matriks banding yang sama letaknya kemudian di akar pangkatkan sesuai dengan jumlah responden sehingga didapatkan matriks perhitungan rata-rata pada tabel berikut ini.

Tabel 3. Perbandingan Rata-rata Kriteria Utama

\begin{tabular}{lllll}
\hline Kriteria & Kekentalan & Sertifikat & Merk & Harga
\end{tabular}

\begin{tabular}{lllll} 
& Oli & Oli & Oli & Oli \\
\hline Kekentalan & 1,000 & 1,692 & 1,117 & 0,768
\end{tabular}

$$
\text { Oli }
$$

\begin{tabular}{lllll}
\hline Sertifikat & 0,591 & 1,000 & 1,991 & 1,104 \\
\hline
\end{tabular}

\begin{tabular}{lllll} 
Oli & & & & \\
\hline Merk Oli & 0,896 & 0,502 & 1,000 & 2,377 \\
\hline
\end{tabular}

\begin{tabular}{lllll}
\hline Harga Oli & 1,302 & 0,906 & 0,421 & 1,000 \\
\hline
\end{tabular}

Sumber: (Marsela et al., 2019)

\section{Sintesis}

Dalam melakukan pertimbangan-pertimbangan terhadap kriteria, maka matriks perbandingan akan dilakukan dengan cara sintesis dengan bertujuan untuk memperoleh keseluruhan prioritas.

Hal-hal yang dilakukan dalam langkah ini yaitu :

1. Menjumlahkan nilai-nilai dari setiap kolom pada matriks.

2. Membagi setiap nilai dari kolom dengan total kolom yang bersangkutan untuk memperoleh normalisasi matriks.

3. Menjumlahkan nilai-nilai dari setiap baris dan membaginya dengan jumlah elemen untuk mendapatkan nilai rata-rata.

Sintesis dilakukan sebanyak jumlah matriks perbandingan yang telah dibuat. Dalam penelitian ini sintesis yang ada meliputi :

1. Sintesis level 1 berdasarkan Kriteria Utama

2. Sintesis level 2 berdasarkan Kekentalan Oli

3. Sintesis level 2 berdasarkan Sertifkat Oli

4. Sintesis level 2 berdasarkan Merk Oli

5. Sintesis level 2 berdasarkan Harga Oli.

Berdasarkan normalisasi kriteria utama. setelah nilai total perhitungan masing-masing kriteria dihitung dengan Vector Eigen, diketahui bahwa kriteria Kekentalan Oli mempunyai nilai total prioritas tertinggi yaitu sebesar 0,267, Sertifikat Oli sebesar 0,262, Merk Oli sebesar 0,258 dan urutan terakhir adalah kriteria Harga Oli sebesar 0,219.
Konsistensi Indeks didapatkan nilai 0,075 atau kurang dari 10\%, lamda 4,224 dan Rasio Konsistensi 0,083. Nilai inkonsistensi sebesar 0,075 sehingga hasil penilaian tersebut masih dapat diterima. Hal ini dikarenakan batas toleransi inkonsistensi $\leq 10 \%$ atau 0,1 .

Jadi berdasarkan perhitungan Vector Eigen, didapatkan kriteria yang paling diperhatikan dalam proses pemilihan Oli Mesin adalah :

1. Kekentalan Oli

2. Sertifikat Oli

3. Merk Oli

4. Harga Oli

Berdasarkan normalisasi kekentalan oli. setelah nilai total perhitungan masing-masing alternatif dihitung dengan Vector Eigen, diketahui bahwa alternatif Vrooam Scooter mempunyai nilai total prioritas tertinggi yaitu sebesar 0,498, alternatif Yamalube Matic sebesar 0,261, dan urutan terakhir adalah Repsol Matic sebesar 0,241.

Konsistensi Indeks didapatkan nilai 0,011 atau kurang dari 10\%, lamda 3,022 dan Rasio Konsistensi 0,019. Nilai inkonsistensi sebesar 0,11 sehingga hasil penilaian tersebut masih dapat diterima. Hal ini dikarenakan batas toleransi inkonsistensi $\leq 10 \%$ atau 0,1 .

Jadi berdasarkan perhitungan Vector Eigen, didapatkan alternatif yang paling diperhatikan dalam proses pemilihan Oli Mesin adalah :

1. Vrooam Scooter

2. Yamalube Matic

3. Repsol Matic

Berdasarkan normalisasi sertifikat oli. setelah nilai total perhitungan masing-masing alternatif dihitung dengan Vector Eigen, diketahui bahwa alternatif Vrooam Scooter mempunyai nilai total prioritas tertinggi yaitu sebesar 0,434, alternatif Repsol Matic sebesar 0,323, dan urutan terakhir adalah Yamalube Matic sebesar 0,243.

Konsistensi Indeks didapatkan nilai 0,019 atau kurang dari 10\%, lamda 3,038 dan Rasio Konsistensi 0,033. Nilai inkonsistensi sebesar 0,019 sehingga hasil penilaian tersebut masih dapat diterima. Hal ini dikarenakan batas toleransi inkonsistensi $\leq 10 \%$ atau 0,1 .

Jadi berdasarkan perhitungan Vector Eigen, didapatkan alternatif yang paling diperhatikan dalam proses pemilihan Oli Mesin adalah :

\section{Vrooam Scooter}


2. Repsol Matic

3. Yamalube Matic

Berdasarkan normalisasi merk oli. setelah nilai total perhitungan masing-masing alternatif dihitung dengan Vector Eigen, diketahui bahwa alternatif Repsol Matic mempunyai nilai total prioritas tertinggi yaitu sebesar 0,354, alternatif Vrooam Scooter sebesar 0,336, dan urutan terakhir adalah Yamalube Matic sebesar 0,310.

Konsistensi Indeks didapatkan nilai 0,018 atau kurang dari 10\%, lamda 3,035 dan Rasio Konsistensi 0,031. Nilai inkonsistensi sebesar 0,018 sehingga hasil penilaian tersebut masih dapat diterima. Hal ini dikarenakan batas toleransi inkonsistensi $\leq 10 \%$ atau 0,1 .

Jadi berdasarkan perhitungan Vector Eigen, didapatkan alternatif yang paling diperhatikan dalam proses pemilihan Oli Mesin adalah :

1. Repsol Matic

2. Vrooam Scooter

3. Yamalube Matic

Berdasarkan normalisasi harga oli. setelah nilai total perhitungan masing-masing alternatif dihitung dengan Vector Eigen, diketahui bahwa alternatif Vrooam Scooter mempunyai nilai total prioritas tertinggi yaitu sebesar 0,411, alternatif Repsol Matic sebesar 0,351, dan urutan terakhir adalah Yamalube Matic sebesar 0,238.

Konsistensi Indeks didapatkan nilai 0,035 atau kurang dari 10\%, lamda 3,070 dan Rasio Konsistensi 0,061. Nilai inkonsistensi sebesar 0,035 sehingga hasil penilaian tersebut masih dapat diterima. Hal ini dikarenakan batas toleransi inkonsistensi $\leq 10 \%$ atau 0,1.

Jadi berdasarkan perhitungan Vector Eigen, didapatkan alternatif yang paling diperhatikan dalam proses pemilihan Oli Mesin adalah :

\section{Vrooam Scooter \\ 2. Repsol Matic \\ 3. Yamalube Matic}

\section{Mengukur Konsistensi}

Dalam proses pembuatan keputusan, penting untuk memahami dan mengetahui konsistensi yang ada berdasarkan pertimbangan dengan konsistensi yang rendah. Berikut ini adalah cara mengukur konsistensi

1. Konsistensi Level 1 Kriteria Utama

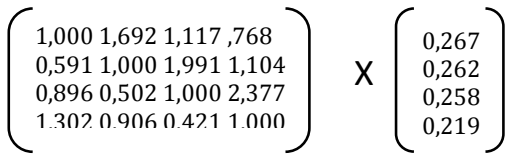

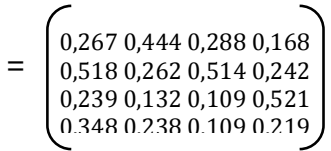

$$
\begin{aligned}
& =\left(\begin{array}{l}
1,167 \\
1,176 \\
1,001 \\
0,914
\end{array}\right):\left(\begin{array}{l}
0,267 \\
0,262 \\
0,258 \\
0,219
\end{array}\right)=\left(\begin{array}{l}
4,369 \\
4,482 \\
3,877 \\
0,219
\end{array}\right)
\end{aligned}
$$

$\lambda$ maksimal $\longrightarrow \quad(4,369+4,482+3,877+$ $0,219) / 4=4,224$

$\mathrm{CI} \longrightarrow(4,224-4) /(4-1)=0,075$

$\mathrm{CR} \longrightarrow 0,075 / 0,900=0,083$

Karena nilai CR $<0,1$ (10\%) maka "dapat diterima", artinya :

Matriks perbandingan berpasangan level 1 berdasarkan Kriteria Utama telah diisi dengan pertimbangan-pertimbangan yang konsisten dan vektor eigen yang dihasilkan dapat diandalkan.

2. Konsistensi Level 2 Kekentalan Oli

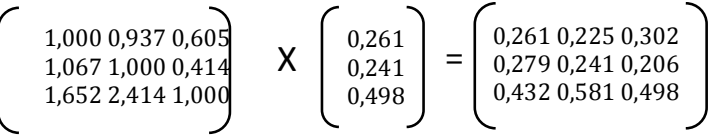

$$
\begin{aligned}
& =\left(\begin{array}{l}
0,788 \\
0,726 \\
1,511
\end{array}\right): \quad\left(\begin{array}{l}
0,261 \\
0,241 \\
0,498
\end{array}\right)=\left(\begin{array}{l}
3,017 \\
3,016 \\
3,033
\end{array}\right) \\
& \lambda \text { maksimal } \longrightarrow(3,017+3,016+3,033) / 3= \\
& 3,022 \\
& \begin{array}{l}
\mathrm{CI} \longrightarrow(3,022-3) /(3-1)=0,011 \\
\mathrm{CR} \longrightarrow 0,011 / 0,580=0,019
\end{array}
\end{aligned}
$$

Karena nilai CR $<0,1 \quad(10 \%)$ maka "dapat diterima", artinya :

Matriks perbandingan berpasangan level 2 berdasarkan Kekentalan Oli telah diisi dengan pertimbangan-pertimbangan yang konsisten dan vektor eigen yang dihasilkan dapat diandalkan.

3. Konsistensi Level 2 Sertifikat Oli

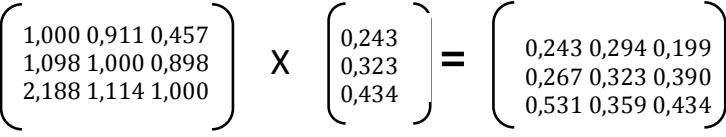

$$
\begin{aligned}
& =\left(\begin{array}{l}
0,735 \\
0,979 \\
1,325
\end{array}\right):\left(\begin{array}{l}
0,243 \\
0,323 \\
0,434
\end{array}\right)=\left(\begin{array}{l}
3,028 \\
3,035 \\
3,050
\end{array}\right)
\end{aligned}
$$

$$
\begin{aligned}
& \lambda \text { maksimal } \longrightarrow(3,028+3,035+3,050) / 3= \\
& 3,038 \\
& \mathrm{CI} \longrightarrow(3,038-3) /(3-1)=0,019
\end{aligned}
$$


CR $0,019 / 0,580=0,033$

Karena nilai CR $<0,1$ (10\%) maka "dapat diterima", artinya :

Matriks perbandingan berpasangan level 2 berdasarkan Sertifikat Oli telah diisi dengan pertimbangan-pertimbangan yang konsisten dan vektor eigen yang dihasilkan dapat diandalkan

4. Konsistensi Level 2 Merk Oli

$$
\begin{aligned}
& (1,0001,0540,764) \\
& 0,9491,0001,273 \\
& 1,3090,7851,000 \\
& X\left(\begin{array}{l}
0,310 \\
0,354 \\
0,336
\end{array}\right)=\left(\begin{array}{l}
0,3100,3730,257 \\
0,2940,3540,428 \\
0,4060,2780,336
\end{array}\right) \\
& =\left(\begin{array}{l}
0,940 \\
1,076 \\
1,020
\end{array}\right):\left(\begin{array}{l}
0,310 \\
0,354 \\
0,336
\end{array}\right)=\left(\begin{array}{l}
3,033 \\
3,037 \\
3,036
\end{array}\right) \\
& \lambda \text { maksimal } \longrightarrow(3,033+3,037+3,036) / 3= \\
& \begin{array}{l}
\mathrm{CI} \longrightarrow(3,035-3) /(3-1)=0,018 \\
\mathrm{CR} \longrightarrow 0,018 / 0,580=0,031
\end{array}
\end{aligned}
$$

Karena nilai CR $<0,1$ (10\%) maka "dapat diterima", artinya :

Matriks perbandingan berpasangan level 2 berdasarkan Merk Oli telah diisi dengan pertimbangan-pertimbangan yang konsisten dan vektor eigen yang dihasilkan dapat diandalkan.

\section{Konsistensi Level 2 Harga Oli}

$$
\begin{aligned}
& \left(\begin{array}{l}
1,0000,5160,744 \\
1,9381,000 \\
1,3441,652
\end{array}\right) \times\left(\begin{array}{l}
0,238 \\
0,038 \\
0,351 \\
0,411
\end{array}\right)=\left(\begin{array}{l}
0,2381,1810,306 \\
0,4610,3510,268 \\
0,3200,5380,411
\end{array}\right) \\
& =\left(\begin{array}{l}
0,725 \\
1,080 \\
1,269
\end{array}\right):\left(\begin{array}{l}
0,238 \\
0,351 \\
0,411
\end{array}\right)=\left(\begin{array}{l}
3,049 \\
3,078 \\
3,085
\end{array}\right) \\
& \lambda \text { maksimal } \longrightarrow(3,049+3,038+3,036) / 3= \\
& 3,070 \\
& \mathrm{CI} \longrightarrow(3,070-3) /(3-1)=0,035 \\
& \mathrm{CR} \longrightarrow 0,035 / 0,580=0,061
\end{aligned}
$$

Karena nilai CR $<0,1$ (10\%) maka "dapat diterima", artinya :

Matriks perbandingan berpasangan level 2 berdasarkan Harga Oli telah diisi dengan pertimbangan-pertimbangan yang konsisten dan vektor eigen yang dihasilkan dapat diandalkan.

Setelah melakukan proses pengukuran konsistensi, maka kegiatan selanjutnya adalah dengan melakukan sintesis global untuk proses pengambilan keputusannya. Adapun prosedurnya yakni :

1. Mengalikan gabungan vektor eigen pada level 2 (level alternatif keputusan) dengan vektor eigen pada level 1 (level kriteria), dan hasil operasi perkalian tersebut selanjutnya disebut sebagai "vektor eigen keputusan".

2. Keputusan yang diambil adalah keputusan yang mempunyai nilai yang paling besar.

3.

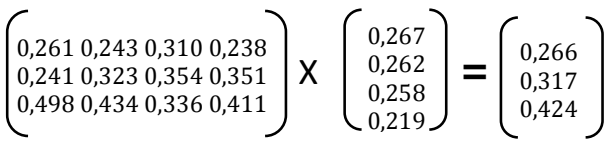

Dari vektor eigen keputusan terlihat bahwa :

1. Vrooam Scooter memiliki bobot prioritas tertinggi yaitu 0,424

2. Repsol Matic memiliki bobot prioritas kedua yaitu 0,317

3. Yamalube Matic memiliki bobot priotitas terendah yaitu 0,266

Jika digambarkan dalan bentuk grafik, maka dapat dilihat jumlah persentasenya sebagai berikut :

\section{Pemilihan Oli Mesin Yamaha Mio dengan AHP}

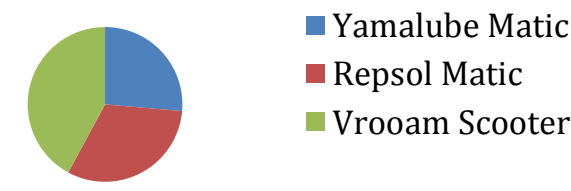

Sumber: (Marsela et al., 2019)

Gambar 2 Persentase Vektor Eigen Keputusan

Berdasarkan vektor eigen keputusan, maka pihak pelanggan Bengkel Blessing Motorsport akan melakukan proses penentuan pemilihan oli mesin. Setelah melakukan perhitungan data di tingkat kriteria dan alternatif, maka selanjutnya dilakukan perhitungan terhadap data akhir, apakah konsisten atau tidak. Perhitungan Rasio Konsistensi Hirarki (CRH) dilakukan dengan cara membagi Concictency Index Hierarki (CIH) dengan Rasio Index Hierarki (RIH) dapat dilakukan dengan rumus :

$\mathrm{CRH}=\mathrm{CIH} / \mathrm{RIH}$

Dimana :

$\mathrm{CIH} \longrightarrow \mathrm{CI}$ Level $1+($ Vektor eigen level 1) $\mathrm{x}$ (CI level 2)

$0,075+\left(\begin{array}{l}0,267 \\ 0,262 \\ 0,258 \\ 0,219\end{array}\right) \times\left(\begin{array}{l}0,011 \\ 0,019 \\ 0,018 \\ 0,035\end{array}\right)$ 


\section{KESIMPULAN}

$0,075+0,020=0,095$

$\mathrm{RIH} \longrightarrow$ RI Level $1+$ (Vektor Eigen level 1) (RI level 2)

$0,900+\left(\begin{array}{l}0,267 \\ 0,262 \\ 0,258 \\ 0,219\end{array}\right) \times\left(\begin{array}{l}0,900 \\ 0,900 \\ 0,900 \\ 0,900\end{array}\right)$
$0,900+0,906=1,806$
CRH $\longrightarrow 0,095 / 1,806=0,053$

Dari perhitungan di atas diperoleh nilai CRH kurang dari 0,1 atau kurang dari 10\%, maka hirarki secara keseluruhan bersifat konsisten, sehingga kesimpulan yang diperoleh dapat diterima, artinya keputusan yang ditetapkan dapat diandalkan. Maka, kesimpulannya didapatkan dari hasil yang telah diperoleh sudah sesuai terhadap hasil hipotesis yang menyatakan bahwa terdapat pengaruh SPK Pemilihan Oli Mesin Yamaha Mio.

Selanjutnya akan dicari prioritas setiap oli mesin berdasarkan kriteria yang ada yakni Kekentalan Oli, Sertifikat Oli, Merk Oli dan Harga Oli. Hal tersebut dapat dilakukan dengan menyusun tabel hubungan yang menggambarkan bobot antara setiap alternatif oli mesin dan kriteria kemudian bobot masingmasing oli dikalikan dengan bobotnya di setiap kriteria dan hasilnya dijumlahkan. Langkah tersebut dipaparkan pada tabel di bawah ini.

Tabel 4. Prioritas Global Pemilihan Oli Mesin

\begin{tabular}{|c|c|c|c|c|c|c|}
\hline $\begin{array}{c}\text { Krite } \\
\text { ria }\end{array}$ & $\begin{array}{c}\text { Ke } \\
\text { ken } \\
\text { tala } \\
\mathrm{n} \\
\text { Oli }\end{array}$ & $\begin{array}{l}\text { Sertifik } \\
\text { at Oli }\end{array}$ & $\begin{array}{c}\text { Merk } \\
\text { Oli }\end{array}$ & $\begin{array}{l}\text { Harg } \\
\text { a Oli }\end{array}$ & $\begin{array}{c}\text { Priori } \\
\text { tas } \\
\text { Globa } \\
1\end{array}$ & $\begin{array}{c}\text { Perin } \\
\text { gkat }\end{array}$ \\
\hline $\begin{array}{l}\text { Yama } \\
\text { lube } \\
\text { Matic }\end{array}$ & $\begin{array}{l}0,3 \\
00\end{array}$ & 0,194 & 0,251 & 0,311 & 1,056 & 3 \\
\hline $\begin{array}{l}\text { Reps } \\
\text { ol } \\
\text { Matic }\end{array}$ & $\begin{array}{l}0,2 \\
05\end{array}$ & 0,381 & 0,419 & 0,419 & 1,278 & 2 \\
\hline $\begin{array}{c}\text { Vroo } \\
\text { am } \\
\text { Scoot } \\
\text { er }\end{array}$ & $\begin{array}{l}0,4 \\
95\end{array}$ & 0,425 & 0,329 & 0,329 & 1,666 & 1 \\
\hline
\end{tabular}

Sumber : (Marsela et al., 2019)

Berdasarkan hasil di atas dapat di lihat bahwa pemilihan oli mesin yamaha mio berdasarkan semua kriteria yakni Kekentalan Oli, Sertifikat Oli, Merk Oli dan Harga Oli diperoleh bahwa Vrooam Scooter menduduki proritas pertama dengan bobot 1,666, diikuti oleh Repsol Matic pada prioritas ke-2 dengan bobot 1,278 dan Yamalube Matic pada prioritas ke-3 dengan bobot 1,506.
Berdasarkan hasil analisa dan pengolahan data yang telah dilakukan oleh penulis, maka dapat diambil beberapa kesimpulan yaitu: (1) Dalam penelitian ini terdapat empat kriteria utama yang digunakan yaitu Kekentalan Oli, Sertifikat Oli, Merk Oli dan Harga Oli. Dimana melalui hasil pengolahan data dari kuesioner ditemukan bahwa Kekentalan Oli dengan bobot $27 \%$ menjadi kriteria yang tertinggi pada pemilihan oli mesin, (2) Pada penelitian ini digunakan tiga alternatif yaitu Yamalube Matic, Repsol Matic dan Vrooam Scooter. Maka alternatif yang lebih prioritas adalah Vrooam Scooter dengan bobot 42\%. (3) Dari hasil perhitungan kuesioner yang telah dibagikan kepada responden menggunakan nilai konsistensi di bawah 0,1 menunjukkan bahwa nilai konsistensi penilaian cukup baik, (4)Urutan prioritas ketiga oli mesin yamaha mio yang dijadikan objek dalam penelitian ini adalah Vrooam Scooter menduduki prioritas pertama dengan bobot 1,665 diikuti oleh Repsol Matic prioritas ke-2 dengan bobot 1,278 dan Yamalube Matic pada prioritas ke-3 dengan bobot 1,506. Oli Mesin Yamaha Mio yang banyak dipilih oleh pelanggan dengan menggunakan Analytical Hierarchy Process (AHP) pada Bengkel Blessing Motorsport Tangerang adalah Vrooam Scooter.

\section{REFERENSI}

Aisyah, S., \& Putra, H. C. (2019). Sistem Pendukung Keputusan Pemilihan Oli Sepeda Motor Matic Terbaik Menerapkan Metode Preference Selection Index, 238248.

Manila, B. C. A., Sutrisno, A., \& Neyland, J. S. . (2014). Penerapan Metode Analytical Hierarchy Process (AHP) Untuk Identifikasi Preferensi Konsumen Pada Pemilihan Minyak Pelumas Sepeda Motor Tipe 4-Tak. Jurnal Online Poros Teknik Mesin, 3 No. 1, 24-36.

Marsela, S., Fridayanthie, E. W., Safitri, M., \& Faridi. (2019). Laporan Penelitian Dosen Yayasan.

Rianto, B., \& Halen, R. val. (2016). Penerapan Metode AHP Untuk Pemilihan Kendaraan Sepeda Motor Matic Studi Kasus Dialer Honda Peranap. Riau Journal of Computer Science, 2(1), 13-22.

Setiawan, S. (2016). Metode Analytical Hierarchy Process Pada Sistem Pendukung Keputusan Penentuan Program Jaminan Sosial, 1(1), 32-41. 
